\title{
Validation Method for Simultaneous Analysis of Betamethasone Dipropionate and Retinoic Acid in Cream Formulation by Ultra High-Performance Liquid Chromatography
}

\author{
Supandi*, Umar Mansyur, Annisa Ananda Ranie, Linda Mazroatul Ulya \\ Department of Pharmacy, Faculty of Health Sciences, Syarif Hidayatullah State Islamic University, Jakarta, Indonesia
}

\begin{abstract}
A simple, precise and rapid reverse phase UHPLC-PDA method has been developed and validated for the simultaneous analysis of betamethasone dipropionate (BTM) and retinoic acid (REA) in whitening cream dosage form. The mixture of betamethasone dipropionate (BTM) and retinoic acid (REA) was separated on Phenomenex Bonclone $10 \mathrm{C}_{18}(150 \mathrm{~mm}$ x $3.9 \mathrm{~mm})$ column. All separations were performed with a Dionex 3000 Photodiode Array (PDA) detector on $240 \mathrm{~nm}$ and $340 \mathrm{~nm}$ wavelength, column temperature at $40^{\circ} \mathrm{C}$, and flow rate at $1.0 \mathrm{ml} / \mathrm{min}$. The mobile phase was methanol-acetic acid $0.1 \%(85: 15)$ with $\mathrm{pH} 5$. The retention times of BTM and REA were found to be 1.90 and 3.70 minutes, respectively. The method showed good linearity with correlation coefficients of 0.9998 and 1.0000 over the ranges of 5-25 ppm for BTM and 25-200 ppm for REA, respectively. The method has mean recoveries in the range of $99.37 \%$ to $100.94 \%$ for all analytes. The developed method can be used in the routine analysis of BTM and REA in cream formulation, as well as for qualitative analysis in whitening cosmetic preparations or for quantitative analysis in drug preparations.
\end{abstract}

Keywords: whitening cream; betamethasone dipropionate; retinoic acid; validation; UHPLC

*corresponding author

Email: supandi@uinjkt.ac.id

\section{INTRODUCTION}

Corticosteroids are highly effective drugs which are used to treat inflammatory skin conditions, such as eczema and psoriasis. Side effects of corticosteroids for long-term use include pustular psoriasis, permanent skin atrophy and systemic effects, such as hypertension, contact dermatitis, and diabetes. Depigmentation is a side effect of topical steroids, thus corticosteroids might be used as whitening agents in topical medical preparations illegally sold as cosmetics. Their absorption through the skin can cause adrenal suppression or even Cushing's syndrome. Local side effects of topical corticosteroids include spreading and worsening of untreated infection; irreversible thinning of the skin, dermatitis, acne, and hypertrichosis (Laurence et al., 2011; Desmedt et al., 2014).

Retinoic acid is an organic acid derived from vitamin A and it is also known as all-trans retinoic acid. It is a drug commonly used to treat acne vulgaris. Acne vulgaris is a common dermatologic problem which could be treated with systemic or topical drugs (Laurence et al., 2011; Deswal et al., 2017). However, retinoic acid is forbidden in Indonesia for all cosmetic preparations (BPOM RI, 2003).
A previous study reported the development and validation of analytical method for simultaneous analysis of retinoic acid, hydroquinone and corticosteroid in cream formulation by high-performance liquid chromatography (Rahmayuni et al., 2018). However, there is not yet an analytical method developed for the simultaneous analysis of combination of betamethasone dipropionate (BTM) and retinoic acid (REA) in cream. Based on the fact that these two components are required to be tested in cream cosmetic preparations (BPOM RI, 2003), especially in facial skin lightening creams, this method also can be used for the assay of those components in drug cream preparations. Thus, this study aimed to develop a fast, simple, inexpensive, sensitive and valid method using ultra high-performance liquid chromatography (UHPLC) for assay of BTM and REA simultaneously in cream. The proposed method was validated with validation parameters of specificity, linearity, limit of detection (LOD) and limit of quantification (LOQ), precision, and accuracy, in accordance with USP guidelines (USP 40, 2016), and later used to analyse creams, both as cosmetic preparations and drug preparations. 


\section{METHODS}

\section{Materials}

This study used commercial whitening topical cream containing both BTM and REA, methanol of liquid chromatography grade (Merck), acetic acid 98-100\% pro analysis (Merck), double distilled water WIDA WI UNICAP $1000 \mathrm{ml}$ (PT Widatra Bhakti, Indonesia), cream base oil-in-water (stearic acid, glycerine, potassium hydroxide) (PT. Ikapharmindo Putramas Jakarta, Indonesia), and reference standards of BTM and REA (PT Unijaya Pratama, Indonesia). The chemical structures of BTM and REA are shown in Figure 1.

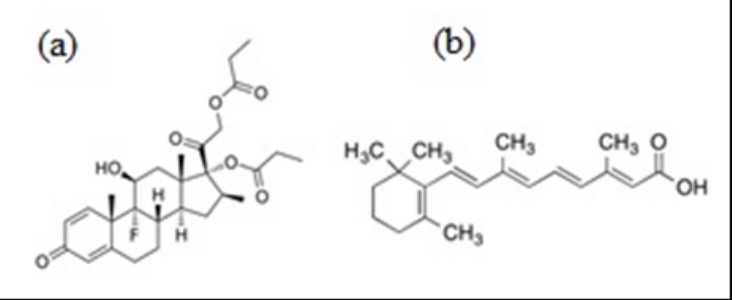

Figure 1. Chemical structures of (a) Betamethasone dipropionate (BTM) and (b) Retinoic acid (REA)

Instrumentation and Chromatographic Conditions All separations were performed on the UHPLC Dionex 3000 with Dionex Photodiode Array (PDA) detector. The data were acquired and analyzed using Chromeleon software. Chromatographic separation was carried out on Phenomenex Bonclone $10 \mathrm{C}_{18}$ (150 mm x 3,9 mm) column. The mobile phase used was methanol-acetic acid $0.1 \%(85: 15)$ with $\mathrm{pH} 5$. Methanol was used as the solvent and acetic acid $0.1 \%$ (in water) was used to set the mixture to be at $\mathrm{pH} 5$. The dilutions of the standards in these mixture would help to stabilize the active substances (BTM and REA) on the instrument (UHPLC).
Before usage, the mobile phase was filtered through 0.45 $\mu \mathrm{m}$ membrane filter and degassed by ultrasonication. The flow rate was maintained at $1.0 \mathrm{~mL} / \mathrm{min}$ with a column temperature of $40^{\circ} \mathrm{C}$. The injection volume was $20 \mu \mathrm{L}$, and the detection was performed at $240 \mathrm{~nm}$ for BTM and $340 \mathrm{~nm}$ for REA using a PDA detector. Validation of the method was performed according to the International Conference on Harmonization (ICH) guidelines (ICH, 1996).

\section{Preparation of Standard Stock Solutions}

The standard stock solutions of BTM and REA were prepared by accurately weighing $12.5 \mathrm{mg}$ of each into a $25 \mathrm{~mL}$ volumetric flask. The drugs were then dissolved in methanol (solvent) until $25 \mathrm{~mL}$. Further dilutions were made from this stock solution to get the concentrations of $5,8,10,15,20$, and $25 \mu \mathrm{g} / \mathrm{mL}$ for BTM and of 25,50 , $75,100,150$ and $200 \mu \mathrm{g} / \mathrm{mL}$ for REA, respectively.

\section{Preparation of Stock Solutions}

An aliquot $(100 \mathrm{mg})$ of the matrices (cream base oilin-water) was weighed into $3 \mathrm{~mL}$ tubes and dilutions were made with $10 \mathrm{~mL}$ of standard stock solution to get solutions with 6 concentrations of $5,8,10,15,20$, and 25 $\mu \mathrm{g} / \mathrm{mL}$ for BTM and 25, 50, 75, 100, 150 and $200 \mu \mathrm{g} / \mathrm{mL}$ for REA, respectively.

\section{Method Validation}

\section{Specificity}

The specificity of this UHPLC method was determined by complete separation of BTM and REA without any interference of excipient peak to the BTM and REA peaks, and by analyzing the resolution (R), tailing factor (TF) and plate count (PC) parameters of each peak, besides the purity plots from PDA detector.

Table 1. The final optimized condition for the analysis

\begin{tabular}{ll}
\hline Parameter & Condition \\
\hline Stationary Phase & Phenomenex Bonclone $10 \mathrm{C} 18(150 \mathrm{~mm} \mathrm{X} \mathrm{3,9} \mathrm{mm).}$ \\
Mobile Phase & A: Methanol; B:Acetic acid 0.1\% in water; A:B $(85: 15) ; \mathrm{pH} 5$ \\
Flow Rate & $1.0 \mathrm{~mL} / \mathrm{min}$ \\
Detection & $240 \mathrm{~nm}, 340 \mathrm{~nm}$ \\
Pump Mode & Isocratic \\
Injection Volume & $20 \mu \mathrm{L}$ \\
Run Time & $6 \mathrm{~min}$ \\
Column Temperature & $40^{\circ} \mathrm{C}$ \\
Retention Time & $\pm 1.90 \mathrm{~min}$ for BTM and $\pm 3.70 \mathrm{~min}$ for REA \\
\hline
\end{tabular}


Table 2. System suitability test parameters

\begin{tabular}{lll}
\hline Parameter & Betamethasone Dipropionate (BTM) & Retinoic Acid (REA) \\
\hline Retention time & $\pm 1.9 \mathrm{~min}$ & $\pm 3.9 \mathrm{~min}$ \\
Theorical plates $(\mathrm{N})$ & 2971.6 & 2622.2 \\
Asymmetry & 0.95 & 0.97 \\
Resolution & 3.0121 & 3.0121 \\
\hline
\end{tabular}

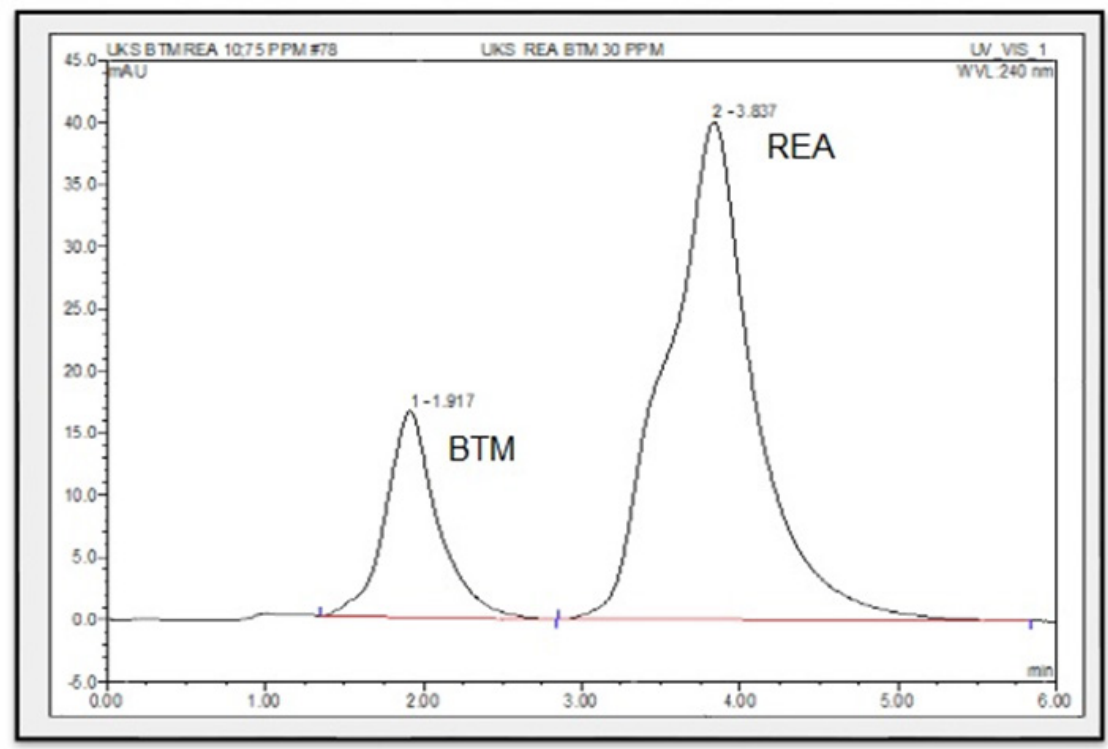

Figure 2. Chromatograms of betamethasone dipropionate (BTM) and retinoic acid (REA)

\section{Linearity and range}

Linearity test was performed with a mixture containing BTM and REA. The standard solution for BTM and REA were diluted to concentrations of $25-150 \mu \mathrm{g} / \mathrm{mL}$ and $25-150 \mu \mathrm{g} / \mathrm{mL}$, respectively. The sorting and dilution were performed quantitatively. Then, the solutions were filtered with a $0.22 \mu \mathrm{m}$ porous filter membrane and injected into the UHPLC system. Chromatograms were recorded. All measurements were repeated three times for each concentration and calibration curve was constructed by plotting the peak areas of analyte versus the corresponding drug concentration (Supandi et al, 2018).

\section{Limits of detection and quantification}

The limit of detection (LOD) and limit of quantification (LOQ) were calculated after the linearity test. The values were calculated from the standard deviation (SD) of response and the slope of the curve (S) with the equations: $\mathrm{LOD}=3.3(\mathrm{SD} / \mathrm{S})$ and $\mathrm{LOQ}=10(\mathrm{SD} / \mathrm{S})$, where $\mathrm{SD}$ is standard deviation of the detector response and $\mathrm{S}$ is slope of the calibration curve (Harmita, 2004).

\section{Precision}

The precision of the proposed method was assessed by preparing three different sample solutions at low, medium, and high concentrations, which were freshly prepared and analyzed. The relative standard deviation (\% RSD) was assessed by analyzing standard drug solutions within the calibration range. The precision of the method was expressed as \% RSD (AOAC, 2002).

\section{Accuracy}

Accuracy was calculated as the difference between theoretical added amount and the practically achieved amount. To check the degree of accuracy of the method, recovery studies were performed in triplicate by standard addition method at $80 \%, 100 \%$, and $120 \%$. The known amount of standard BTM and REA were added to preanalyzed samples and were subjected to the proposed method (Petrova et al., 2013).

\section{Application for analysis of commercial cream}

The validated method was then used for testing cream samples from an online market. The sample used in this test was a whitening cream. A portion of the cream was weighed about $500 \mathrm{mg}$ into the appropriate tube to get $100 \mu \mathrm{g} / \mathrm{ml}$ concentration. The sample was extracted with methanol with the aid of ultrasonication for 15 minutes, and then filtered using $0.45 \mu \mathrm{m}$ porous filter membrane. 


\section{RESULTS AND DISCUSSION}

\section{Chromatographic Conditions}

A satisfactory separation and good peak symmetry were obtained in the optimized conditions by using the described methanol-acetic acid $0.1 \%$ (85:15) with $\mathrm{pH}$ 5. The flow rate was $1.0 \mathrm{~mL} /$ minutes and oven temperature for column was set to $40^{\circ} \mathrm{C}$. Using PDA detector, the chromatograms was read with Chromeleon Chromatography software by using time wavelength procedure. BTM and REA were measured at the optimum wavelengths of $240 \mathrm{~nm}$ and $340 \mathrm{~nm}$, respectively (Table 1). The system suitability parameters for UHPLC chromatogram are as follows (Table 2). The average retention times for BTM and REA were found to be 1.90 and 3.70 minutes, respectively (Figure 2).

\section{Specificity}

This UHPLC method was in accordance to the specificity parameter. The chromatograms of BTM and REA were completely separated from each other and without any interference from excipient peak (Figure 2). The resolution (R), plate count (PC), and asymmetry parameters of each peak also met the requirements, which were $\geq 2$ for $R, \leq 2$ for asymmetry and $\geq 2000$ for PC (Table 2) (Bendre \& Ghule, 2016).

\section{Linearity and Range}

The value of Vxo of each component was $\leq 2.0$ and $\mathrm{r}$ value was $\geq 0.9990$, which confirmed the good linearity of this method (Table 3). Linear regression data for the calibration plots revealed good linear relationships between response and correlation. The linear regression equations were $\mathrm{y}=0.6388 \mathrm{x}+0.6166$ for $\mathrm{BTM}$, and $\mathrm{y}=$ $0.3151 \mathrm{x}+0.1109$ for REA (Table 3 ).

Table 3. Specificity, range, LOD and LOQ parameters

\begin{tabular}{lll}
\hline Parameter & Betamethasone Dipropionate (BTM) & Retinoic Acid (REA) \\
\hline Linearity range, $\mu \mathrm{g} / \mathrm{ml}$ & $5-25$ & $25-200$ \\
Regression equation & $\mathrm{y}=0.6388 \mathrm{x}+0.6166$ & $\mathrm{y}=0.3151 \mathrm{x}+0.1109$ \\
$\mathrm{r}^{2}$ & 0.9997 & 1.0000 \\
$\mathrm{r}$ & 0.9998 & 1.0000 \\
Slope & 0.6388 & 0.3151 \\
Y-intercept & 0.6166 & 0.1109 \\
LOD $(\mu \mathrm{g} / \mathrm{mL})$ & 1.28 & 8.42 \\
LOQ $(\mu \mathrm{g} / \mathrm{mL})$ & 3.87 & 25.51 \\
Precision $(\mathrm{RSD} \%)$ & $0.93 \%$ & $0.50 \%$ \\
\hline
\end{tabular}

Table 4. Accuracy parameter

\begin{tabular}{lll}
\hline Concentration $(\boldsymbol{\mu g} / \mathbf{m L}) *$ & Accuracy (\% Recovery) \\
\hline BTM & 5 & \pm 100.38 \\
& 15 & \pm 99.37 \\
& 25 & \pm 100.00 \\
\hline REA & 25 & \pm 100.94 \\
& 100 & \pm 99.87 \\
& 200 & \pm 99.98 \\
\hline
\end{tabular}

* Average from three repetitions

\section{Limits of Detection and Quantification}

The LOD and the LOQ for this simultaneous analysis were found to be $1.27 \mu \mathrm{g} / \mathrm{mL}$ and $3.86 \mu \mathrm{g} / \mathrm{mL}$ for BTM, and $8.41 \mu \mathrm{g} / \mathrm{mL}$ and $25.51 \mu \mathrm{g} / \mathrm{mL}$ for REA, respectively (Table 3).

\section{Precision}

The values of RSD $\%$ were found to be $0.93 \%$ from BTM and $0.50 \%$ for REA (Table 3 ). These values indicate that the repeatability of this method is satisfactory (Huber, 2007).

\section{Accuracy}

The recovery values were between $99.37-100.38 \%$ for BTM and $99.87-100.94 \%$ for REA, which indicate that the method is accurate (Table 4). 
Table 5. Assay of commercial creams

\begin{tabular}{lll}
\hline \multirow{2}{*}{ Cream } & \multicolumn{2}{c}{ Containing } \\
\cline { 2 - 3 } & $\mathrm{BTM} *(\%)$ & $\mathrm{REA} *(\%)$ \\
\hline $\mathrm{A}$ & 2.41 & 0.01 \\
$\mathrm{~B}$ & 0.11 & 0.11 \\
$\mathrm{C}$ & 0.25 & $\mathrm{~N} . \mathrm{A}$ \\
$\mathrm{D}$ & 0.60 & 3.30 \\
$\mathrm{E}$ & 0.65 & 3.53 \\
\hline N.A Not applicable & \\
* Average from three repetitions &
\end{tabular}

\section{Application for Analysis of Commercial Cream}

The peaks obtained with PDA detector at 240 and 340 $\mathrm{nm}$ for BTM and REA, respectively, from commercial creams were sharp and well-defined. The measurement results are presented in Table 5. The result of this study proves that UHPLC with this method can be used for analysis of BTM and REA simultaneously in cream preparations.

\section{CONCLUSION}

The mixture of betamethasone dipropionate (BTM) and retinoic acid (REA) can be separated using UHPLC method with mobile phase of methanol-acetic acid $0.1 \%$ $(85: 15)$ at $\mathrm{pH} 5$, Phenomenex Bonclone $10 \mathrm{C}_{18}(150 \mathrm{~mm}$ x $3.9 \mathrm{~mm}$ ) column at temperature of $40^{\circ} \mathrm{C}$, flow rate at $1.0 \mathrm{ml} / \mathrm{min}$, and Dionex 3000 Photodiode Array (PDA) detector on $240 \mathrm{~nm}$ and $340 \mathrm{~nm}$ wavelengths for BTM and REA, respectively. The proposed UHPLC method is accurate, precise, sensitive, selective, and rapid for the simultaneous determination of BTM and REA in a cream formulation.

\section{ACKNOWLEDGMENT}

The reference standards of BTM and REA were kindly gifted by PT Unijaya Pratama. The authors also thankful to the Faculty of Health Sciences, UIN Jakarta for providing necessary facilities.

\section{REFERENCES}

Association of Official Analytical Chemist. (2002). Official Methods of Analysis of AOAC International, AOAC International.

Bendre, S., \& Ghule, P. (2016). Analytical method development validation, and assay of betametasone dipropionate cream by HPLC method . International Research Journal of Pharmacy, 7(12), 74-83.

Badan POM RI. (2003). Keputusan Ka Badan POM
RI No HK.00.05.4.1745, tentang Kosmetik, Badan Pengawas Obat dan Makanan RI. Jakarta

Brunton, L., Chabner, B., \& Knollman, B. (2011). Goodman \& Gilman's the pharmacological basis of therapeutics (12th ed.). New York: McGraw-Hill Companies Inc.

Depkes RI, (1995). Farmakope Indonesia Edisi ke IV. Jakarta: Direktorat Jenderal Pengawasan Obat Dan Makanan.

Harmita. (2004). Petunjuk Pelaksanaan Validasi Metode dan Cara Perhitungannya, Majalah Ilmu Kefarmasian (Vol. 1). Depok: Departemen Farmasi FMIPA Universitas Indonesia.

Huber, Ludwig.(2007).Validation and Quantification in Analytical Laboratories, London:Infoma.

International Conference on Harmonization (1996). Technical Requirements for Registration of Pharmaceuticals of Human Use, ICH Harmonized Tripartite Guidelines Validation of Analytical Procedure: Text and Methodology Q2(R1), Geneva, Switzerland.

Laurence, B. (2011). Goodman \& Gilman's the pharmacological basis of therapeutics 12th ed. New York: McGraw-Hill Companies .

Petkova, N., Brabant, P., Masson, An., \& Denev, P. (2013). HPLC analysis of mono and disaccharides in food products, Science works of UFT, Volume LX, "Food Science, engineering and technologies", 18-19 October 2013, Plovdiv, 761-765.

Rahmayuni, E., Harmita, H., \& Suryadi, H. (2018). Development and validation method for simultaneous analysis of ratinoic acid, hydroquinone and corticosteroid in cream formulation by High-Performance Liquid Chromatgrography. Journal of Applied Pharmaceutical Science, 8(09), 087-092 
Sastrohamodjojo, H. (2002). Kromatografi, 67-77, Universitas Gadjah Mada, Yogyakarta.

Supandi, Yahdiana H., Harmita., Rizka A., (2018). Simultaneous analysis of 6-Mercaptopurine, 6-Methylmercaptopurine, and 6-Thioguanosine5'-monophosphate in dried blood spot using ultra performance liquid chromatography tandem mass spectrometry. Indonesian Journal of Chemistry, 18 (3), $544-551$.

United States Pharmacopoeia (40 th ed.). Rockville: The United States Pharmacopeial Convention. 2016. 